\title{
Analysis of the Relationship between Quadrilaterals Achievement Levels and Van Hiele Geometric Thinking Levels of the Seventh Grade Students
}

\author{
Meryem Ersoy ${ }^{1}$, Onur Alp İlhan ${ }^{2} \&$ Sevim Sevgi ${ }^{2}$ \\ ${ }^{1}$ Graduate School of Educational Sciences, Erciyes University, Kayseri, Turkey \\ ${ }^{2}$ Mathematics and Science Education Department, Faculty of Education, Kayseri, Turkey \\ Correspondence: Onur Alp İlhan, Mathematics and Science Education Department, Faculty of Education, \\ Kayseri, Turkey. Tel: 90-543-915-3652. E-mail: oailhan@erciyes.edu.tr
}

\author{
Received: April 9, 2019 Accepted: May 10, 2019 Online Published: June 4, 2019 \\ doi:10.5539/hes.v9n3p1 URL: https://doi.org/10.5539/hes.v9n3p1
}

\begin{abstract}
In this study, it was aimed to examine the relation between seventh-grade students' quadrilaterals achievement levels and Van Hiele geometric thinking levels. Survey method was used. The sample of the study was 160 students from the three different districts of Kayseri, as Melikgazi, İncesu, and Tomarza. Van Hiele geometric thinking test and quadrilaterals achievement test, which was developed by the first researcher, were used to collect the data. Descriptive statistics such as mean, frequency, and standard deviation and percentage tables Pearson correlation analysis which was applied to analyze the relationship between the quadrilaterals achievement test and Van Hiele geometry thinking test scores of the seventh-grade students and independent samples t-test was used to for analysis. The results of the study indicated that Van Hiele geometric thinking levels of the seventh school students were lower than expected levels. A high level of correlation was found between quadrilaterals achievement levels and their Van Hiele geometric thinking levels of the seventh-grade students. As a result of the study, quadrilaterals achievement test and Van Hiele geometric thinking test were measuring the students' geometric abilities in the same direction.
\end{abstract}

Keywords: Van Hiele, geometry thinking, quadrilaterals, geometry, 7th grade

\section{Introduction}

The importance of knowledge and information in today's world is increasing very rapidly as knowledge, science and information concepts change. Many concepts and perceptions change with the advancing technology and science. In order to keep up with this rapid change and innovation, the knowledge and skills expected from new generations changes. This rapid change and innovations should be followed in the field of education for future generations. In order not to fall behind the era, we need to regulate our education programs for this renewed knowledge and science.

Mathematics is a system of order. In other words, mathematics is a branch of science that examines numbers, shapes and the relationship between them to put in order. It is also a language built on shapes and symbols. Information around us is interpreted, edited and predicted with mathematics (Ocak and Çimenci Ateş, 2015). The ability to know and use mathematics, which is an important area in our daily lives, and the need for mathematics are increasing rapidly. In the changing and developing world, people who know mathematics and those working on it are one step ahead of the future. In line with the needs of change and development, mathematics education must gain meaning again and educators need to restructure by adapting to new or changed requirements and development. Making, understanding and interpreting mathematics change over time with the improvements in the new technologies, to illustrate the complex calculations made in the past are now very easy with the calculators and computers. Time-varying mathematical perception has become increasingly important. As such, more problem solving skills and higher level thinking skills have gained more importance. People now have easily got access to all the information they want. It is not as hard as it used to be. For this reason, the ability to use mathematical development and thinking to keep up with time and development have increased over time and have become very important for elementary students.

Mathematics achievement is measured and analyzed at the national curriculums. In Turkey, it is seen that the 
average score of mathematics is always very low compared to other branches at the national exams such as the end of middle school exams, and university entrance examinations. Moreover, considering the averages of mathematics and science scores is important in International Examinations such as Trends in International Mathematics and Science Study [TIMSS] and Program for International Student Assessment [PISA]. The mathematics and science courses average scores of Turkey are very low after the curriculum changes in the new applied curriculum (Duru and Korkmaz, 2010 as cited in Ocak and Çimenci Ateş, 2015). TIMSS which is an International Examination conducted for the fourth and seventh-grade students has been made every 4 years since 1995. In 2011, a total of 42 countries, $4^{\text {th }}$ and $8^{\text {th }}$-grade students, participated in the TIMSS. Turkish eighth-grade level students have participated to TIMSS in 1999, 2007, 2011 and 2015. When we analyze the results, it is seen that Turkey has left only 16 countries behind. The reason why we cannot achieve success in these important international examinations makes us think to move further (Ocak and Çimenci Ateş, 2015).

Unfortunately, the level of mathematics achievement was not at the level we wanted. The mathematics curriculum was also developed in the direction of constructivist theory by getting rid of its old rigid behaviorist structure. It was firstly implemented in the 2005-2006 academic year. As a result of the renewed curriculums, 12 years of compulsory education and some evaluations, there have been changes in some subjects over time. In addition, a middle school mathematics curriculum was introduced in 2013 (Ocak and Çimenci Ateş, 2015). The renewed mathematics curriculum is based on the idea that every child can learn mathematics. The most of concepts related to mathematics are abstract by its nature than the other sciences; it is not easy to detect when children are learned the concepts according to their level of development. For this reason, basic concept knowledge about mathematics is handled based on concrete and finite life models (MoNE, 2009).

In a learning environment organized with a constructivist approach, students gain experience by utilizing general mathematical methods such as abstractions, explanations, symbolizations, generalizations, proofs and new questions through activities. These methods are directly related to the realization of the subject and to the realization of meaningful learning. In addition to these, it is also learned that certain concepts and skills will be needed for the activities and studies to be carried out for the exploration of purposes (Ocak and Çimenci Ateş, 2015).

It is a set of systems that suggest thinking in mathematics. It enables us to understand our environment and our world. Mathematics consists of a variety of structures and relationships. This system is the whole of the outgoing systems. It proceeds in the process of abstraction and generalization. From this point on, we can understand how mathematics is actually an abstract structure. And the concept of abstract concepts and definitions is not easy at all (Baykul, 2014)

Doing mathematics does not mean you can just solve many questions or pass exams by imitating a teacher in the lesson. It is more than that. Doing mathematics is developing a strategy to solve problems, implementing this strategy and reaching to a conclusion. This method is found and the result is building connection abstraction to real life. Knowing how to transfer abstract mathematical things to real life is really different for students. The more we model these problems in the real world, the more mathematics we have done in daily life (Van de Walle, Karp, Bay-Williams, Wray and Brown, 2007). National Council of Teachers of Mathematics (NCTM) (1998; 2000) emphasized that one of the most fundamental sub-areas of mathematics is geometry to build this connection If we need mathematics in our daily lives, we need geometry. We can imagine that they have completed each other and that mathematics without geometry will be incomplete. Geometry has a lot of applications in daily life. These are usually various objects and shapes we often meet in our own lives. We can give examples of buildings around us, many things we use, the houses we live in and many more. The geometry will only be too much to see, such as shape information or angles and edges. Geometry completes mathematics as well as helping to establish the relationship between other branches. This way of thinking is also associated with other disciplines and it is beneficial for students to use their reasoning abilities actively.

Geometric thinking is very important if we set out from reasoning abilities. It enables students to stimulate their reasoning abilities and to increase their ability to comment on different disciplines. The aim of geometry and mathematics is to enable the students to overcome the problems that may be encountered in their lives. Although they appear to be composed of shapes and rules, they should be able to use them in solving their problems. Mathematics and geometry become more meaningful if we create this awareness in students. This is why mathematics and geometry are necessary for elementary grades (Ülger, 2003).

\subsection{Van Hiele Geometric Thinking Theory}

Geometrical thinking structures are the basics of the thinking structures and how many of these thinking structures have been developed are important for students. For years, the studies on this subject continued in a 
spiral manner. The most prominent of these studies is started with the "Van Hiele model" by Dina Van Hiele Geldof and her husband Pierre Marie Van Hiele. This study that emerged in 1957 has attracted the attention of many researchers around the world. Van Hiele theory formed the basis of several studies related to the geometry at the literature (Erdoğan, 2006; Olkun and Toluk, 2003). Van Hiele theory played a very important role in understanding geometry, interpreting and determining the development of geometric thinking levels. The theory has also been the source of even wider reviews by providing practice in the classroom. In van Hiele's theory, students must actively participate in the activities prepared to achieve the expected goals and explore the features related to geometrical definitions (Gutierrez, 1992).

The most striking point in the van Hiele model is that it divides the levels of geometric thinking into five levels. Each of these levels constitutes the level of thinking. The aim of the levels is to determine the students' perspective and mental processes rather than the achievement levels at geometry. The difference between the levels is related to the perspective of geometry (van de Walle et al., 2007). The levels found in the Van Hiele model are as follows:

\subsubsection{Level I: Visualization}

What is thought at the visualization level is to know the shapes and what they look like. Only the outward appearance of the figures is considered. Therefore, the elements of the shapes and features of the students were in the first place of knowing and interpreting geometric shapes.

Geometric shapes are evaluated at this level only by their appearance. Elements and properties of geometric shapes, not the size of the shape, are evaluated according to the stance. If a student at this level is shaped and then the figure is rotated, he will recognize this shape (Duatepe Paksu, 2016). If a square object is given to the student, the square may be called square if it is shown in advance. And every object that looks like a square will say square. A student at the visualization level will call Figure $1 \mathrm{~b}$ a thin rectangle if it is mentioned as a rectangle. However, Figure 1c cannot be thought of as a rectangle (Duatepe Paksu, 2016).

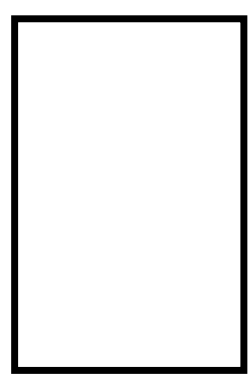

Figure 1a

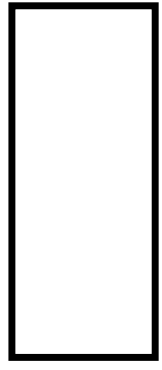

Figure 1b

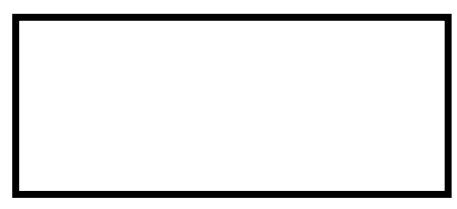

Figure 1c

What is the most fundamental at this level is actually the difference between shapes or figures that students can recognize. The general purpose at the visualization level is to classify the figures according to their common characteristics. Seeing similarities and differences between the sides of the given figures improves students' ability about distinguishing. The instructional activities in geometry according to Level 1 can be:

- Classification and separation activities can be performed.

- Students need two-dimensional or three-dimensional objects and activities that can draw, form, disassemble, and gather together and complete these pieces. These activities should be based on different features of objects. Thus, students gain an understanding of geometry.

- To help them move from Level 1 to Level 2, they should be asked about challenging questions. Students should be forced to think (Van de Walle et al., 2007).

At the visualization level, students perceive the features and the details of objects and shapes together. To support students to move from level 1 (visual period) to level 2 (analysis):

- Make sure that the figures shown in the lesson is chosen from daily life.

- Opportunities should be provided for students to draw shapes and shreds and assemble them.

- Thinking environments related to figures should be created.

- Our aim is not just to give the definition, but to show the shapes one to one and give examples. 
The activity to be done for the students at the visualization level and some suggestions can be:

- Classification of shapes according to common characteristics.

- Play and search objects and shapes and find them.

- Matching games with geometric shapes.

- Jigsaw, completion, drawing activities.

- Shapes of various patterns.

- Give examples from daily life to geometric shapes (Şahin, 2008)

1.1.2 Level II: Analysis

At the second level of the van Hiele model which is analysis, students begin to understand the properties of shapes and geometric objects. They know all the features of shapes. Students are busy with shape classes rather than shapes, know and interpret all properties of a shape as well as comprehend the sum of the features of the shapes in detail. Various generalizations can be found between the shapes. They define each shape separately, but they cannot see the common points of the two different shapes. Based on this, they cannot reason about the properties of shapes. To improve the geometric thinking of students at the level of analysis:

- Include studies in the form of continuation of the visualization level.

- To measure the length of geometric objects used, to calculate the angle of the work.

- Classify geometric shapes according to their properties.

Some studies and various activities for students at this level are as follows:

- Write down the properties of the objects given.

- Building shapes with the help of various materials.

- Measuring the dimensions of geometric objects and shapes.

- Classification activities can be done (Şahin, 2008).

At this level, analysis of geometric shapes is more important for the student than for the appearance of the shapes. Comprehension is a valid mind competence for this level. For students, the features are more important than the appearance of the shape. At this level, students can separate the square, rectangle, and parallelogram from each other according to their characteristics, but they cannot comprehend the common features of each other and that each square is a rectangle. They cannot see whether the properties of the shapes are related to each other. For example, they know that the opposite sides are parallel to each other in a parallelogram, but they cannot establish the relationship between the parity of the sides. In other words, students do not know that it should be parallel and reasons behind the being parallel (Duatepe, 2016).

The most noticeable difference between Level 1 and Level 2 is the object of thought. While students in Level 2 continue to use models and draw shapes, they begin to see them as representations of shape classes (Van de Walle et al., 2007). To enable students to pass from Level 2 to Level 3, let them say "Why?" Students should be forced to think and reason with questions such as questions and questions that push the mind skill on the subject (Van de Walle et al., 2007).

\subsubsection{Level III: Abstraction}

What are thought to be experienced in their abstraction level are the features of shapes. At this level, students recognize the relationships between shapes. At this level, students can classify shapes among themselves and they can see the relationship between them. For example, they call a rectangle with four right angles and they know it. The figure says that if it is a square, it has four right angles and the square is actually a rectangle. You can use expressions such as if you connect. At the abstraction level, students classify and know the shape properties. To improve the geometric thinking style and structure of students at abstraction level:

- Students should be informed about what the shapes they use in class or everyday life. They may be asked to produce ideas.

- Some drawing activities can be done.

The deduction could not be at this level. In other words, the student cannot make definitive decisions at different general knowledge about shapes. Abstraction level course is in daily life and some of the activities and recommendations can be made as follows: 
- Draw the drawings of shapes

- Write and draw the properties of geometric shapes.

- Prepare games to recognize and compare geometric shapes (Şahin, 2008).

At the informal level, students should be able to say the desired and expected characteristics in the definition of a concept and feature since they realize the relationships between the figures. Instead of telling the features of a figure for a long time, students can express more clearly and simply. For example, they understand and learn that a shape can have more than one definition (Duatepe Paksu, 2016).

At the level of experiential inference, students make inferences about the features of shapes and shapes and proceed within the framework of logic. They do not go step-by-step, but they can perceive it intellectually (Van de Walle et al., 2007). Teaching techniques according to Level 3 can be applied as follows:

- They should be encouraged to create and test hypotheses and assumptions. For example, "Is this true for all triangles or is it only for isosceles triangles?" as.

- Non-formal extraction language should be used "All, some, sometimes, not at all then", "What happens if" etc. (Van de Walle et al., 2007).

\subsubsection{Level IV: Deduction}

At the level of deduction, students perceive much more advanced forms than their features. Only the property is not enough for the student. Beyond that, there is no questioning that almost everything is completely unacceptable. They go slowly to the proof of induction. They can make this proof in their own minds (Şahin, 2008).

At this level, the student can follow a proof, why it is applied, and the process steps. (S)He can use the methods given. In other words, the proof is not requested to be given directly and memorized from it. The student can reveal his ability to prove himself (Şahin, 2008). A student at the level of inference can work with abstract concepts and find reasonable results. A student can easily prove this level (Şahin, 2008).

In Level 4, a student knows that the diagonals of the rectangle center each other. However, he knows that he must prove this in an inferential way. A student in Level 3 follows logical processes but does not need much (Van de Walle et al., 2007). A student at this level on the basis of previously proven theorems (s)he can bring more to prove in any other theorem, understands the process of induction by the method of induction. In Level 4, students comprehend the concepts of proof, theorem and what they do (Duatepe Paksu, 2016). The level of a student who comes to Level 4 is high school geometry. They try to create an inferential system with the geometry learned at the high school level. They define the theorems and build on postulates. They use logical reasoning to prove the theorems (Van de Walle et al., 2007).

\subsubsection{Level V: Rigor}

Systematic thinking is what is being considered to find out the relationships between different systems. They compare the axiomatic systems with each other and draw their own theorems. Non-Euclidean geometry can work. The object of systematic thinking is the axiomatic system that results in the object of thinking. At this level, students study geometry as a science. The level of systematic thinking is at the highest level of Van Hiele level. Due to this, the reason for this is axiomatic systems. Students at the level of systematic thinking are at the university level. It is even a student studying geometry (Şahin, 2008).

At this level, the students find the axiom. The definitions are insufficient and they can obtain theorems in different axiomatic systems. They understand and interpret the geometries that are other than Euclid. They can form theorems other than Euclidean geometry. For example, Euclid's "can be drawn toward the outside of the right only a line from a point" instead of expressing Riemann's "One cannot be drawn parallel from one point to the outside" and Lobatchevski of "a right can be drawn parallel many from a point outside." can understand and interpret the expression. In the Euclidean geometry, the total angle of a triangle is 180 degrees and it can be detected. The reasons why Riemann and Lobatchevski are used 180 degrees in their geometries. They perceive that the existence of more than one geometric system does not mean that only one will be true (Duatepe Paksu, 2016).

The research problem of the study is "What are seventh-grade students Van Hiele geometric thinking the levels about quadrilaterals subject? Sub-research problems are:

- What are the Van Hiele geometry thinking levels of seventh-grade students?

- Is there a significant relationship between Van Hiele geometry thinking test and the quadrilateral 
achievement test of the seventh-grade students?

- Is there a significant mean difference between the schools in terms of geometric thinking levels of Van Hiele and quadrilateral achievement test?

- Is there a significant mean difference between the level of Van Hiele geometric thinking test and quadrilaterals achievement test of seventh grade students in terms of boys and girls?

\section{Method}

Survey method was used in the study of seventh-grade students in terms of quadrilaterals achievement test and Van Hiele geometric thinking levels test.

\subsection{Sample}

This study has been applied to students from 3 different districts of Kayseri. 105 students from School 3 in Melikgazi district of Kayseri, 41 students from School 2 in İncesu district of Kayseri and 14 students from School 1 in Tomarza district of Kayseri were participated to study. Quadrilaterals achievement test and Van Hiele geometric thinking test tests were applied to a total 160 of students. Schools were chosen because it was known that the families of the students in the sample were social, economic and culturally different and at they are rural area schools. School 3 is a school in the center of Kayseri and is higher in social, economic and cultural terms. School 2 is in Toki region of İncesu district and it is in social, economic and cultural medium level. School 3 is in the village of Üçkonak in the Tomarza district and has lower social, economic and cultural aspects.

\subsection{Data Collection Tool}

Quadrilaterals achievement test, Van Hiele Geometric thinking test was administered to the seventh-grade students for data collection.

\subsubsection{Van Hiele Geometry Test}

The Van Hiele Geometry Test developed by Usiskin was used to determine the geometry level of seventh-grade students. The test was adapted to Turkish by Duatepe (2004). Reliability and validity studies were conducted by the Duatepe. There are 25 questions in the Van Hiele geometry test. In this study, the first 15 questions were used for data collection since these first 15 items were appropriate for the middle school students' levels. In the Van Hiele test are 1-5 questions for Level 1; 6-10 questions for Level 2; 11-15 questions for Level 3, 16-20 questions for Level 4 and 21-25 questions for Level 5. If students answer three of the first five questions right; then student who reaches the first level answers three of the next five questions, the second level is determined. A student who cannot reach level 1 cannot go to level 2 even if he makes three of this level's questions correctly. Van Hiele Geometry Levels are in hierarchical order. The characteristics of the Van Hiele Geometry Thinking Test are given in Table 1.

Table 1. Characteristics of Van Hiele Geometry Thinking Test (Altun, 2015, p. 163)

\begin{tabular}{lll}
\hline Questions & Levels & Features of the questions \\
\hline $1-5$ & 1 & It is related to visual shapes. Determines whether students recognize shapes. \\
$6-10$ & 2 & It relates to the properties of different shapes. \\
$11-15$ & 3 & It shows whether the students know the relationship between shapes. \\
$16-20$ & 4 & They are questions about logical deduction. \\
$21-25$ & 5 & Whether Euclidean or Euclidean reasoning was reasoning. \\
\hline
\end{tabular}

\subsubsection{Quadrilaterals Achievement Test}

In order to measure the achievement levels of the seventh-grade students in quadrilaterals, achievement test of quadrilaterals with 20 questions was prepared by the first researcher. Three experts' opinions and five middle school mathematics teachers' opinions were taken. Objectives of the mathematics curriculum which was written by the MoNE at the academic year 2017-2018 were used for the test design. The objectives of the Ministry of National Education in the 2017-2018 academic years are as follows:

"1. Recognizes rectangular, parallelogram, trapezoidal and rhombus; determines the angle properties.

\section{Form the area formula of quadrants of rectangular and rectangular; solve the problems.}

3. Solves problems related to the area." (MoNE, 2013, p. 89)

The order of the items in the quadrilaterals achievement test is designed according to the order of mathematics objectives in the elementary mathematics curriculum. While preparing the questions, 3 experts' and 3 middle 
schools mathematics teachers' opinions were taken. The experts agreed that the questions were suitable for measuring the objectives of the quadrilaterals.

\subsection{Data Collection}

The quadrilateral achievement test and Van Hiele geometry test were used to collect data. Ethical permission has been given by the MoNE for the administration of both tests; students were given 40 minutes (1 lesson hour). At the end of the given time, tests were collected by the first researcher.

\subsection{Data Analysis}

The data obtained from the Van Hiele geometry test and quadrilaterals achievement test were analyzed in SSPS program. Descriptive analyses (average, standard deviation, frequency values) are calculated. Pearson correlation was applied to find the relationship between the tests. One-way analysis of variance (ANOVA) runs for the analysis of differences between schools for both tests. Independent samples t-test run to analyse the gender differences at both of the tests.

\section{Results}

The results of the study obtained through Van Hiele Geometry test and quadrilaterals achievement test were interpreted at this part.

\subsection{Van Hiele Geometric Thinking Levels of Schools}

First sub-problem of the study, "What is the level of Van Hiele geometric thinking levels of seventh-grade students?" is analyzed. Students' Van Hiele geometric thinking levels were given at the Table 2 according to the distribution of Van Hiele levels across schools.

Table 2. Distribution of Van Hiele Geometric Thinking Levels across schools

\begin{tabular}{lllllll}
\hline School & \multicolumn{2}{c}{ School 1 } & \multicolumn{2}{c}{ School 2 } & \multicolumn{2}{c}{ School 3 } \\
Levels & f & \% & f & \% & f & \% \\
\hline Level 0 (Not belonging to any level) & 2 & 14.2 & 6 & 14.63 & 31 & 29.52 \\
Level 1 (Visualization) & 9 & 64.2 & 21 & 51.21 & 54 & 51.42 \\
Level 2 (Analysis) & 2 & 14.2 & 9 & 21.95 & 12 & 11.42 \\
Level 3 (Informal Inference) & 1 & 7.14 & 5 & 12.19 & 8 & 7.61 \\
Total & 14 & 100 & 41 & 100 & 105 & 100 \\
\hline
\end{tabular}

When Table 2 is analyzed, the two students of the School 1 were at level 0, 9 students were at level 1, 2 students were at level 2, 1 student was at level 3. Majority of the students in the school $2(64.2 \%)$ were at level 1 . As a result, most of the students in school 1 were in the visualization period of Van Hiele geometric thinking test. At School 2; 6 students were at level 0, 21 students were at level 1, 9 students were at level 2, 5 students were at level 3 of Van Hiele geometric thinking test. As a result, seventh-grade students in School 2 were generally at level 1, visualization period. Seventh-grade students of the School 3; 31 students were at level 0, 54 students were at level 1, 12 students were at level 2, 8 students were at level 3. As a result, it is seen that most of the students in School 3 were in level 1, visualization period. Majority of the seventh-grade students were at level 1.

\subsection{Correlation between Van Hiele Geometric Test and Quadrilaterals Achievement Test}

In the second sub-problem of the study, "Is there a significant relationship between the seventh-grade students' Van Hiele geometric thinking levels and their score from the quadrilaterals achievement test?" is analyzed. In order to reach the results of this relationship, the Pearson correlation coefficient was examined. The relationship between quadrilaterals achievement test and Van Hiele geometry test scores were calculated as 0.56 . It means that there is a significant relationship between the scores of the students at Van Hiele Geometry test and the quadrilaterals achievement test. Quadrilaterals achievement test is similar to van Hiele test since both of them measures similar things.

\subsection{Difference across Schools in Van Hiele Geometric Thinking Test}

In the third sub-problem of the study "Is there a significant mean difference between the schools in terms of Van Hiele geometric thinking levels of?" is analyzed. The maximum number of correct answers and the minimum number of correct answers to the points taken by Van Hiele geometry test in schools is given in Table 3. 
Table 3. Van Hiele Geometric Thinking Test Scores of Schools

\begin{tabular}{lllllll}
\hline School & $\mathbf{n}$ & $\overline{\mathbf{x}}$ & SD & Standard error & Minimum Score & Maximum Score \\
\hline School 1 & 14 & 6.14 & 2.59 & 0.69 & 3 & 12 \\
School 2 & 41 & 7.51 & 2.22 & 0.34 & 2 & 12 \\
School 3 & 105 & 6.22 & 2.43 & 0.23 & 1 & 15 \\
Total & 160 & 6.54 & 2.44 & 0.19 & 1 & 15 \\
\hline
\end{tabular}

According to Table 3, the average of Van Hiele geometric thinking test scores of the students was 6.41 in School 1, 7.51 in School 2 and 6.22 in School 3. A minimum score of Van Hiele geometric thinking test was at School 1 across schools. The highest number of correct answers belongs to School 3 with 15 questions. The lowest correct numbers that are given to Van Hiele geometry test are respectively in School 1, School 2, and School 3. Van Hiele geometry test the correct number of the highest order at School 1 was 12, was 12 at School 2 and was 15 at School 3 .

Levene's statistics applied to determine whether the variances are distributed homogeneously. The level of significance of the Levene's statistics is 0.94 which indicated there is no significant variance in schools in terms of Van Hiele Geometric Thinking levels.

The One-Way Analysis of Variance (ANOVA) to determine whether there is a significant mean difference across the schools in terms of Van Hiele Geometric Thinking levels. The results of ANOVA verified that there is a significant mean difference in terms of Van Hiele geometric thinking levels $F(2,157)=4.516, p=0.012<0.05)$. In order to determine the origin of differentiation between schools, Scheffe test was used for post-hoc tests.

Table 4. Scheffe Test for Schools

\begin{tabular}{llllll}
\hline $\begin{array}{l}\text { School (I)- } \\
\text { School (J) }\end{array}$ & $\begin{array}{l}\text { Mean } \\
\text { Difference (I-J) }\end{array}$ & $\begin{array}{l}\text { Standard } \\
\text { error }\end{array}$ & Sig. $(\boldsymbol{p})$ & $\begin{array}{l}\text { Upper Confidence } \\
\text { Interval }\end{array}$ & $\begin{array}{l}\text { Lower Confidence } \\
\text { Interval }\end{array}$ \\
\hline School 1- School 2 & -1.369 & .741 & .158 & -3.12 & .38 \\
School 1- School 3 & -.076 & .681 & .993 & -1.69 & 1.54 \\
School 2- School 3 & 1.293 & .441 & .011 & .25 & 2.34 \\
\hline
\end{tabular}

According to the results of the Scheffe test of the Van Hiele geometry test; there was no significant difference between School 1 and School 2, p = 0.158; School 1 and School 3, p = 0.993; but there is a significant mean difference results between School 2 and School 3, p = 0.011. As School 2 and School 3 have $p=0.011<0.05$, there are significant mean differences among these schools in favor of School 2.

\subsection{Difference across Schools in Quadrilaterals Achievement Test}

In the fourth sub-problem of the study, "Is there a significant difference between the schools in terms of the quadrilaterals achievement test?" is analyzed. Descriptive statistics of the quadrilaterals achievement test was given in Table 5 across schools.

Table 5. Descriptive Statistics of Circle Achievement Test

\begin{tabular}{lllllll}
\hline School & $\mathbf{n}$ & $\overline{\mathbf{x}}$ & SD & Standard error & Minimum Score & Maximum Score \\
\hline School 1 & 14 & 9,50 & 5,14 & 1,37 & 3 & 19 \\
School 2 & 41 & 13,98 & 4,63 & 0,72 & 6 & 20 \\
School 3 & 105 & 11,67 & 4,40 & 0,43 & 3 & 19 \\
Total & 160 & 12,07 & 4,68 & 0,37 & 3 & 20 \\
\hline
\end{tabular}

In Table 5, the mean of the correct answers given by seventh-grade students of School 1 to the quadrilaterals achievement test is 9.50. The mean of the students' achievement test of School 2 was 13.98 and the mean of the students' achievement test of School 3 was 11.67. The lowest right answers given to the quadrilaterals achievement test were 3, in School 1, 6 in School 2 and 3 in School 3, respectively. The highest right answers given to the quadrilaterals achievement test was 19 by the students in School 1, 20 in School 2 and 19 in School 3.

The Levene's statistics significance was $(\mathrm{p}=0.91>0.05)$ which indicated there is no significant variance in schools in terms of quadrilaterals achievement test. Table 9 presents the findings of ANOVA to determine whether there is a significant mean difference across schools in terms of quadrilaterals achievement test. There is 
significant mean difference at the quadrilaterals achievement test between the schools $(\mathrm{F}(2,157)=6.293 \mathrm{p}=$ $0.002<0.05$ ). In order to determine the cause of this difference, the Scheffe test was used for post-hoc tests.

Table 6. Scheffe test for quadrilaterals achievement test

\begin{tabular}{|c|c|c|c|c|c|}
\hline \multirow[t]{2}{*}{ School (I)-School (J) } & \multirow{2}{*}{$\begin{array}{l}\text { Mean } \\
\text { Difference (I-J) }\end{array}$} & \multirow[t]{2}{*}{ Std. Error } & \multirow[t]{2}{*}{ Sig. } & \multicolumn{2}{|c|}{ 95\% Confidence Interval } \\
\hline & & & & Lower Bound & Upper Bound \\
\hline School 1-School 2 & $-4.476^{*}$ & 1.403 & 0.005 & -7.79 & -1.16 \\
\hline School 1-School 3 & -2.167 & 1.289 & 0.216 & -5.22 & 0.88 \\
\hline School 2-School 3 & 2.309 & 0.834 & 0.017 & 0.33 & 4.28 \\
\hline
\end{tabular}

According to the results of the Scheffe test analysed to the quadrilaterals achievement test; School 1 and School 2 was $p=0.005$; School 1 and School 3 was $p=0.216$; School 2 and School 3 was $p=0.017$. There is a significant mean difference in favor of School 2 among the schools as it is $\mathrm{p}=0.005<0.05$ between School 1 and School 2. There are significant differences in favor of School 2 since School 2 and School 3 are $p=0.017<0.05$.

\subsection{Gender Difference at Van Hiele Geometric Thinking Test and Quadrilaterals Achievement Test}

In the fifth sub-problem of the study, "Is there a significant mean difference between seventh-grade boys and girls at the Van Hiele geometric thinking test and quadrilaterals achievement test?" is analyzed. The distribution of boys and girls seventh-grade students in the Van Hiele geometric thinking levels test is given in Table 7.

Table 7. Gender Distribution at Van Hiele geometric thinking levels

\begin{tabular}{lll}
\hline Van Hiele Levels & Girls & Boys \\
\hline Level 0 (Not belonging to any level) & 19 & 20 \\
Level 1 (Visualization) & 37 & 46 \\
Level 2 (Analysis) & 13 & 11 \\
Level 3 (Informal Inference) & 6 & 8 \\
Total & 75 & 85 \\
\hline
\end{tabular}

When Table 7 is analyzed, it was seen that 19 of the female students were at level 0, 37 girls were at level 1, 13 girls were at level 2, and 6 girls were at level 3.20 boys were at level 0, 46 boys were at level 1, 11 boys were at level 2 , and 8 boys were at level 3 . Independent samples t-test was run to determine whether there is a significant mean difference between Van Hiele levels between boy and girl students.

Van Hiele geometry test scores mean of girls was 6.65 ( $\mathrm{SD}=2.39$ ), while Van Hiele geometry test scores mean of boys was $6.45(\mathrm{SD}=2.5)$. No significant mean difference was found between the Van Hiele geometry test scores of the boys and girls of seventh-grade students ( $\mathrm{t}(148)=0.53, \mathrm{p}=0.66>0.05)$. Similarly, independent samples $t$-test was run to determine whether there was a significant mean difference between quadrilaterals achievement test scores of seventh-grade boy and girl students. Quadrilaterals achievement test scores mean of girl students was $13.63(\mathrm{SD}=4.43)$ and the mean of quadrilaterals achievement test of boy students was $10.69(\mathrm{SD}=4.47)$. There is no significant mean difference was found between the boy and girl students of quadrilaterals achievement test scores $(\mathrm{t}(148)=4.15, \mathrm{p}=0.92>0.05)$.

\section{Discussion}

This study was conducted in middle schools in three different districts of Kayseri with a total of 160 seventh-grade students. Van Hiele geometry thinking levels were lower than the desired level in the first sub-problem of this study. In this study, there are $14(8.75 \%)$ students who reach the third level. 23 students (14.37\%) were at level 2, $84(52.5 \%)$ were at level 1, 39 (24.37\%) were students at level 0. As seen, most of the students are at level 1 . Considering seventh-grade quadrilateral objectives, it is very difficult for level 1 students to understand these objectives. Fidan and Türnüklü (2010) analyzed the fifth-grade students' geometry thought levels. In their study, geometric levels were examined according to the grade level, gender, education level of parents at Izmir with a total of 1644 students According to the results of the study, it was found that $47.9 \%$ of the participants were at level 0,29.3\% were at first level, $16.7 \%$ were at second level and $6.1 \%$ were at third level. Depending on this, half of the students are on level 0. As it is seen here, the levels were lower than expected.

In the second sub-problem of the study, the relation of the quadrilateral achievement test and Van Hiele geometric thinking test was 0.56 . As a result, it can be said that there is a significant relationship between the two tests. These tests were in a similar manner.

In the results of the third sub-problem of the study, the mean of the responses of the seventh-grade students to the 
Van Hiele geometry test was calculated 6.54. According to the analysis results, the mean of Van Hiele geometric test; 6.14 School 1; In School 2, it was 7.51 and in School 3 was calculated as 6.22. Urban and rural area schools percentages are different than each other.

In the fifth sub-problem of the study, it was analyzed whether the Van Hiele geometry test changes according to gender. According to the results, the Van Hiele geometry test of female students is 6.65, while the Van Hiele geometry test of male students is 6.45 . There was no significant mean difference between boys and girls. Seventh grade students who are majority of them at the visualization level did not differentiate according to their gender. At the visualization level gender does not differentiate students. Moreover, it was examined whether the achievement of the quadrilaterals test varies according to gender. According to the results obtained from the quadrilaterals achievement test of girl students' mean 13.63, the boys' achievement test mean was 10.69. On average, girls were more successful than boys. There was no significant mean difference between the results of $t$ test in the quadrilaterals achievement test of boys and girls $(\mathrm{p}=0.92>0.05)$. Similar to van Hiele geometric thinking test results, this result can be linked with students van Hiele geometric thinking levels.

Suggestions of the future studies:

- Research should be carried out with a bigger sample than this study.

- Instead of only using gender and schools, socioeconomic status, mothers and fathers education level should be added to study.

- Students attitudes toward geometry and mathematics and self-efficacy should be controlled at the further studies.

\section{Acknowledgement}

This work was supported by Erciyes University Scientific Research Projects Unit (Project Code: SYL-2018-7930). This article is derived from Meryem Ersoy's Master's Thesis entitled "Analyze of the relationship between quadrilaterals achievement levels and Van Hiele geometric thinking levels of the 7th grade students", conducted under the supervision of Onur Alp İlhan.

\section{References}

Altun, M. (2005). Matematik Öğretimi, Bursa: Alfa Akademi Basın Dağıtım.

Altun, M. (2002). Matematik ögretimi, Bursa: Erkam Matbaacılık.

Baykul, Y. (2014). Illkokulda Matematik Öğretimi, Pegem Yayıncılık 12. Baskı.

Duatepe, A. (2004). The effects of drama based instruction on seventh grade students' geometry achievement, Van Hiele geometric thinking levels, attitude toward mathematics and geometry. Unpublished doctoral dissertation, Middle East Technical University, Ankara, Turkey. https://doi.org/10.1080/13569780500053767

Paksu, A. D. (2013). Sınıf öğretmeni adaylarının geometri hazır bulunuşlukları, düşünme düzeyleri, geometriye karş1 özyeterlikleri ve tutumları. Pamukkale Üniversitesi Eğitim Fakültesi Dergisi, 33(33), 203-218.

Duatepe, P. A. (2016). Van Hiele Geometrik Düşünme Düzeyleri. E. Bingölbali, S. Arslan, ve İ. Ö. Zembat (Eds.), Matematik eğitiminde teoriler (pp. 265-274). Ankara: Pegem Akademi.

Duru, A., \& Korkmaz, H. (2010). Teachers' views about a new mathematics curriculum and difficulties encountering curriculum change. Hacettepe University Journal of Education, 38, 67-81.

Fidan, Y., \& Türnüklü, E. (2010). Examination of 5th grade students' levels of geometric thinking in terms of some variables. Pamukkale University Journal of Education, 27(27), 185-197.

Gutiérrez, Á. (1992). Exploring the links between Van Hiele Levels and 3-dimensional geometry. Structural Topology, núm 18.

Gutiérrez, A. (1996). Visualization in 3-dimensional geometry: In search of a framework. In L. Puig \& A. Guttierez (Eds.), Proceedings of the 20th conference of the international group for the psychology of mathematics education, vol. 1 (pp. 3-15). Valencia: Universidad de Valencia.

Milli Eğitim Bakanlığı (2005). İlköğretim matematik dersi 1-5.sinıflar Öğretim Programı, Ankara.

Milli Eğitim Bakanlığı (2009). İlköğretim matematik dersi 1-5.sinıflar Öğretim Programı, Ankara.

Milli Eğitim Bakanlığı (2010). İlköğretim matematik dersi 1-5.sinıflar Öğretim Programı, Ankara.

Milli Eğitim Bakanlığı (2013). İlköğretim matematik dersi 1-5.sinıflar Öğretim Programı, Ankara. 
Milli Eğitim Bakanlığı. (2018). Matematik dersi ögretim programı (ilkokul ve ortaokul 1, 2, 3, 4, 5, 6, 7 ve 8. Siniflar), Ankara.

NCTM, (1998). Commission on Standards for School Mathematics. Curriculum and evaluation standards for school mathematics. National Council of Teachers of Mathematics.

NTCM, (2000), Curriculum and Evaluation Standards for School Mathematics.

Ocak, G., \& Çimenci, A. F. (2015). Matematik dersinde yapılandırmacı yaklaşımın uygulanabilirliğinin öğretmen görüşleri açısından değerlendirilmesi. Uluslararası Alan Eğitimi Dergisi, 1(2), 1-23.

Şahin, O. (2008). In-pre-service elementary school teachers'Van Hiele reasoning stages. Unpublished Master's thesis, Afyon Kocatepe University Graduate School of Social Science, Afyonkarahisar.

TDK, (Türk Dil Kurumu) (1998). Türkçe Sözlük (9.bs.). Ankara: Türk Dil Kurumu Yayınları.

Türnüklü, E., \& Özcan, B. N. (2014). The relationship between students' construction of geometric knowledge process based on RBC theory and Van Hiele geometric thinking levels: case study. Mustafa Kemal University Journal of Graduate School of Social Sciences, 11(27), 295-316.

Ülger, A. (2003). Matematiğin kısa bir tarihi. Matematik Dünyası, 2, 49-53.

Van de Walle, J. A., Karp, K. S., Bay-Williams, J. M., Wray, J. A., \& Brown, E. T. (2007). Elementary and middle school mathematics: Teaching developmentally, Boston: Allyn and Bacon.

\section{Copyrights}

Copyright for this article is retained by the author(s), with first publication rights granted to the journal.

This is an open-access article distributed under the terms and conditions of the Creative Commons Attribution license (http://creativecommons.org/licenses/by/4.0/). 